\title{
Tool Geometry Influence on Surface Integrity of Machined Austenite Stainless Steel
}

Zdeněk Pitrmuc ${ }^{1}$, Jiří Čapek ${ }^{2}$, Kamil Kolařík ${ }^{2}$, Libor Beránek ${ }^{1}$, Jan Urban ${ }^{1}$

${ }^{1}$ Department of Machining, Process Planning and Metrology, Faculty of Mechanical Engineering, Czech Technical University in Prague. E-mail: libor.beranek@fs.cvut.cz, zdenek.pitrmuc@fs.cvut.cz

${ }^{2}$ Department of Solid State Engineering, Faculty of Nuclear Sciences and Physical Engineering, Czech Technical University in Prague. E-mail: capekjir@fjfi.cvut.cz, kamil.kolarik@fjfi.cvut.cz

The goal of this contribution was to describe the microstructure and properties changes of difficult to cut materials after turning. Surface residual stresses, roughness, microstructure of AISI 304 type stainless steel were studied as a function of side rake angle $\gamma_{0}$. Residual stresses and phase composition of surface and sub-surface layers were determined using X-ray diffraction techniques. The presence of strain-induced martensite was investigated using Barkhausen noise, optical microscope, and microhardness measurement.

Keywords: Austenite Stainless Steel, Strain-induced Martensite, Tool Geometry, Residual Stresses, Roughness

\section{Acknowledgement}

This work was supported by the governmental funding of Technological Agency of Czech Republic-project number TA04020658.

\section{References}

[1] MOVERARE, J. J., ODEN, M. (2002). Deformation behaviour of a prestrained duplex stainless steel. In: Materials Science and Engineering: A, Vol. 337, No. 1, pp. 25 - 38.

[2] JANG, D. Y., WATKINS, T. R., KOZACZEK, K. J., HUBBARD, C. R., CAVIN, O. B. (1996). Surface residual stresses in machined austenitic stainless steel. In: Wear, Vol. 194, No. 1, pp. $168-173$.

[3] M'SAOUBi, R., OUTEIRO, J. C., CHANGEUX, B., LEBRUN, J. L., DIAS, A. M. (1999). Residual stress analysis in orthogonal machining of standard and resulfurized AISI 316L steels. In: Journal of materials processing technology, Vol. 96, No. 1, pp. 225 - 233.

[4] MARTIN, M., WEBER, S., IZAWA, C., WAGNER, S., PUNDT, A., THEISEN, W. (2011). Influence of machining-induced martensite on hydrogen-assisted fracture of AISI type 304 austenitic stainless steel. In: International Journal of Hydrogen Energy, Vol. 36, No. 17, pp. 11195 - 11206.

[5] HAUSILD, P., KOLARIK, K., KARLIK, M. (2013). Characterization of strain-induced martensitic transformation in A301 stainless steel by Barkhausen noise measurement. In: Materials \& Design, Vol. 44, pp. 548 - 554.

[6] CHEN, H. T., YAN, M. F., FU, S. S. (2014). Martensite transformation induced by plasma nitrocarburizing on AISI304 austenitic stainless steel. In: Vacuum, Vol. 105, pp. 33 - 38.

[7] LV, J., LUO, H. (2014). Effects of strain and strain-induced $\alpha^{\prime}$-martensite on passive films in AISI 304 austenitic stainless steel. In: Materials Science and Engineering: C, Vol. 34, pp. $484-490$.

[8] MOORE, M. G., EVANS, W. P. (1958). Mathematical correlation for stress in removed layers in X-ray diffraction residual stress analysis. In: SAE Technical Paper, Vol. 66, pp. 340.

[9] AZANZA RICARDO, C. L., D’INCAU, M., SCARDI, P. (2007). Revision and extension of the standard laboratory technique for X-ray diffraction measurement of residual stress gradients. In: Journal of Applied Crystallography, Vol. 40, pp. $675-683$.

[10]THEINER, W. A. (1998). Physical basis of micromagnetic methods and sensor systems and their application areas. In: Proceedings of the 1st International Conference on Barkhausen noise and Micromagnetic Testing, pp. 197 218. Hannover.

[11]THEINER, W. (1986). Stress measurements on components with nondestructive ferromagnetic methods. In: Residual Stresses in Science and Technology, Vol. 1, pp. 167 - 174.

[12]TIITTO, S., SAYNAJAKANGAS, S. (1975). Spectral damping in Barkhausen noise. In: IEEE Transactions on Magnetics, Vol. 11, No. 6, pp. 1666 - 1672. 
[13]SAGLAM, H., UNSACAR, F., YALDIZ, S. (2006). Investigation of the effect of rake angle and approaching angle on main cutting force and tool tip temperature. In: International Journal of Machine Tools and Manufacture, Vol. 46, No. 2, pp. $132-141$.

[14]VASILKO, K. (2009). Teória a prax trieskového obrábania, pp. 35 - 82. COFIN, Prešov.

[15]VASILKO, K. (2014). New experimental dependence of machining. In: Manufacturing Technology, Vol. 14, No. 1 , pp. $111-116$.

[16]GUPTA, M., KUMAR, S. (2015). Investigation of surface roughness and MRR for turning of UD-GFRP using PCA and Taguchi method. In: Engineering Science and Technology, an International Journal, Vol. 18, No. 1, pp. $70-81$.

Copyright (C) 2016. Published by Manufacturing Technology. All rights reserved. 